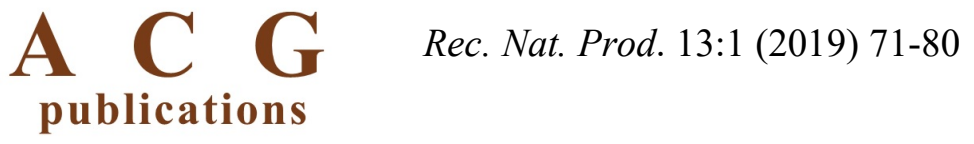

records of natural products

\title{
Chemical Constituents and Anti-influenza Viral Activity of the Leaves of Vietnamese Plant Elaeocarpus tonkinensis
}

\section{Nga Thu Dao $\odot^{1,4 \dagger}$, Yejin Jang $\odot^{2 \dagger}$, Meehyein Kim $\odot^{2}$, Hung Huy Nguyen $\odot^{3}$, Duong Quang Pham $\odot^{4}$, Quang Le Dang $\odot^{5^{*}}$, Minh Van Nguyen $\odot^{6}$, Bong-Sik Yun ${ }^{6}$, Quan Minh Pham $\odot^{7}$, Jin-Cheol Kim $\odot^{8^{*}}$ and Vu Dinh Hoang ${ }^{1^{*}}$}

\author{
${ }^{1}$ School of Chemical Engineering, Hanoi University of Science and Technology, Hanoi, 10000, Vietnam \\ ${ }^{2}$ Virus Research Group, Korea Research Institute of Chemical Technology, Gajeong-ro, \\ Yuseong-gu, Daejeon 34114, Korea \\ ${ }^{3}$ Center for Advanced Chemistry, Duy Tan University, Da Nang 55000, Vietnam \\ ${ }^{4}$ Center for High Technology Development, Vietnam Academy of Science and Technology, \\ Hanoi 10000, Vietnam \\ ${ }^{5} R \& D$ Center of Bioactive Compounds, Vietnam Institute of Industrial Chemistry, Hanoi, \\ 10000, Vietnam \\ ${ }^{6}$ Division of Biotechnology, College of Environmental and Bioresource Sciences, Chonbuk \\ National University, Jeonju-si, Jeollabuk-do 54896, Korea \\ ${ }^{7}$ Institute of Natural Products Chemistry, Vietnam Academy of Science and Technology \\ ${ }^{8}$ Department of Agricultural Chemistry, Institute of Environmentally Friendly Agriculture, College of \\ Agriculture and Life Sciences, Chonnam National University, Gwangju 61186, Korea
}

(Received April 02, 2018; Revised May 23, 2018; Accepted May 24, 2018)

\begin{abstract}
Various Elaeocarpus species including Elaeocarpus tonkinensis have been important medicinal plants that used in traditional medication system and mainly used to cure nervous system-related disorders. However, their antiviral potential has not been reported yet. During the screening of medicinal plant extracts with the antiviral activity against influenza viruses, we found that E. tonkinensis extract has strong antiviral activity. Through organic solvent partition and repeated column chromatography using $\mathrm{SiO}_{2}, \mathrm{C}-18$ and Sephadex LH-20, a total of nine compounds were purified from the methanol extract of E. tonkinensis. Their chemical structures were determined by NMR and MS spectral data to be trolliamide (1), gallic acid (2), urolithin M-5 (3), hydroquinone (4), 2,4-dihydroxybenzoic acid (5), 3,5-dihydroxy-4-methoxybenzoic acid (6), corilagin (7), chebulagic acid (8), and shikimic acid (9). Their antiviral activity against influenza virus strains A/Puerto Rico/8/34 (H1N1; PR8), A/Hong Kong/8/68 (H3N2; HK) and B/Lee/40 (Lee) was examined on the basis of cytopathic effect (CPE) assay. Among them, compounds 2, 3, 4, 7, and 8 significantly inhibited viral replication in a dose-dependent manner with $\mathrm{EC}_{50}$ values ranging from 7.8 to $59.6 \mu \mathrm{g} / \mathrm{mL}$ against influenza $\mathrm{A}$ and/or $\mathrm{B}$ viruses with selectivity indices above 5.0. This study suggests that the botanical materials of E. tonkinensis could be promising inhibitors of influenza A and B viruses and applied to the development of a novel herbal medicine.
\end{abstract}

Keywords: Influenza virus; Elaeocarpus tonkinensi; antiviral activity; infectious disease. (C) 2018 ACG Publications. All rights reserved.

"Corresponding authors: E-Mail: vudinhhoanghn@gmail.com (H.D. Vu), Phone: +84914661299; kjinc@jnu.ac.kr (J.-C. Kim), Phone: +82625302132, Fax:+82625302139; quangledang2011@gmail.com (Q.L. Dang), Phone: +84913001862; 'Denotes equal contribution. 


\section{Introduction}

Influenza occurs with seasonal variations and reaches peak prevalence in winter with many people killed worldwide every year. To date, only a few organic compounds including amantadine, rimantadine, zanamivir, and oseltamivir phosphate (OSV-P) have been used for influenza therapy. However, drug-resistant influenza viruses are generated quickly. Thereby, it is attractive and urgent to seek new influenza drugs. In our screening of plant extracts against influenza viruses, we found that the methanol extract and EtOAc layer of $E$. tonkinensis exhibited antiviral activity.

Elaeocarpus tonkinensis A. DC. (E. tonkinensis) commonly called Com Bac Bo, is a member of family Elaeocarpaceae. It is small timber with a height of $10 \mathrm{~m}$ and white yellow and soft wood. In Viet Nam, it is mainly distributed in Nghe An, Thanh Hoa, Tuyen Quang, Bac Thai and Quang Ninh provinces at 100-500 m [1]. Various Elaeocarpus species have been used in traditional medication system such as to cure infectious diseases and nervous system related disorders. Studies indicated that Elaeocarpus species contain various chemical constituents including triterpenes, tannins, alkaloids, flavonoids, and glycosides [2,3], with different therapeutic activities: cytotoxic [4], anti-microbial [5], antidepressant [6], anti-diabetic [7,8], analgesic [9], asthma [10] effects. However, their anti-influenza viral activity has not been reported yet.

During the screening of plant extracts against influenza viruses, we found that the methanol extract and ethyl acetate (EtOAc) layer of E. tonkinensis exhibited the significant antiviral activity. Therefore, the objectives of this study were to examine the antiviral activities of its crude extracts against influenza virus strains including A/Puerto Rico/8/34 (H1N1; PR8), A/Hong Kong/8/68 (H3N2; $\mathrm{HK}$ ) and $\mathrm{B} /$ Lee/40 (Lee), and to isolate and identify effective metabolites.

\section{Materials and Methods}

\subsection{General Experimental Procedures}

Silica gel $60 \AA$ grade (particle sizes 40-63 $\mu \mathrm{m}$ ) for column chromatography was purchased from Merck (Darmstadt, Germany). Sephadex LH-20 beads (size 25-100 $\mu \mathrm{m}$ ) were purchased from SigmaAldrich (St Louis, MO). Medium Pressure Liquid Chromatography (MPLC) (CombiFlash ${ }^{\circledR ~ R f+}$ system with a column C18 (43 g); 40-60 $\mu \mathrm{m})$ system was used for isolation of active metabolites. HPLC system used for isolation and analysis consisted of a Hitachi L-2455 diode array detector, L2130 HPLC pump, EZchrom elite data system with a $\phi 4.6 \times 150 \mathrm{~mm}$ (TOSOH, RP-18, Japan), $\phi 10 \times$ $150 \mathrm{~mm}$ (Cosmosil, RP-18, Japan) column. Thin-layer chromatography (TLC) plates (silica gel 60 $\mathrm{F}_{254}$, thickness $0.2 \mathrm{~mm}$ ) were obtained from Merck (Germany). Chemical spots on TLC plates after development were detected using $p$-anisaldehyde-sulfuric acid (AS) and ferric chloride staining reagents, or with $10 \% \mathrm{H}_{2} \mathrm{SO}_{4}$ in methanol. All solvents were distilled and purified before use.

\subsection{Plant Material}

Leaves and twigs of E. tonkinensis were collected in Vu Quang National Parks (Ha Tinh), Vietnam and identified by Dr. Do Ngoc Dai, Department of Forestry, Nghe An University of Economics. A voucher specimen (No.1-MS.104.01-2014.34) has been deposited in the School of Chemical Engineering, Hanoi University of Science and Technology.

\subsection{Extract Preparation and Isolation of Pure Compounds}

Dried and powdered leaves and twigs of E. tonkinensis $(9.5 \mathrm{~kg})$ were extracted with $\mathrm{MeOH}-\mathrm{H}_{2} \mathrm{O}$ $(8: 2)$ at room temperature $(3 \times 24 \mathrm{~h})$. The methanol extracts were combined and concentrated under vacuum at $55^{\circ} \mathrm{C}$. The obtained residue was suspended in water and successively partitioned with $n$ hexane, dichloromethane (DCM) and ethyl acetate (EtOAc) to afford $247.8 \mathrm{~g} n$-hexane, $50.1 \mathrm{~g} \mathrm{DCM}$, and $241.4 \mathrm{~g}$ EtOAc residues, respectively. The $n$-hexane residue $(20 \mathrm{~g})$ was fractionated on a silica gel column [600 g silica gel $60 \AA(40-63 \mu \mathrm{m})]$ and eluted using mixtures of $n$-hexane-DCM (1:0 and 0:1, 
v/v) and DCM-MeOH (1:0 and 9:1, v/v) to give 70 fractions (Fr.1 - Fr.70). Fraction Fr.44 (2.5 g) was repeatedly chromatographed on a silica gel column $[50 \mathrm{~g}$ silica gel $60 \AA(40-63 \mu \mathrm{m})]$ with mixtures of $n$-hexane-DCM (1:0 and 0:1, v/v) and DCM-MeOH $(1: 0$ and 9:1, v/v) yielding $20 \mathrm{mg}$ compound 1.

The EtOAc residue (20 g) was subjected to column chromatography (400 g silica gel $60 \AA$ (40-63 $\mu \mathrm{m})$ with $\mathrm{DCM}-\mathrm{MeOH}(100: 0$ and 7:3, v/v), giving 40 fractions. Fraction Fr.15 $(0.6 \mathrm{~g})$ was subjected to sephadex LH-20 chromatography eluting with $\mathrm{DCM}-\mathrm{MeOH}(1: 1, \mathrm{v} / \mathrm{v})$ to give 15 fractions. The fractions Fr.15.6 and Fr.15.10 were combined and crystallized from DCM-MeOH (9:1, v/v) to give crystals of compounds 2 and 3, respectively. Fr.23 (0.4 g) was applied to a MPLC system [43 g C-18 $(40-60 \mu \mathrm{m}), 1 \times 15 \mathrm{~cm}$, eluting with $\mathrm{MeOH}-\mathrm{H}_{2} \mathrm{O}(2: 8$ and $\left.1: 0, \mathrm{v} / \mathrm{v})\right]$, then purified by preparative HPLC with $150 \times 10 \mathrm{~mm} \mathrm{C}-18$ column, $\mathrm{MeOH}-\mathrm{H}_{2} \mathrm{O}$ stepwise gradient (1:9 to 3:7, v/v), and flow rate of $3.0 \mathrm{~mL} / \mathrm{min}$. Compounds $4(29.1 \mathrm{mg}), \mathbf{5}(8.9 \mathrm{mg})$, and $\mathbf{6}(4.3 \mathrm{mg})$ were eluted at RT $21 \mathrm{~min}$, RT 25 min and RT 35 min, respectively. Fraction F34 was also chromatographed by MPLC with a stepwise gradient elution of $\mathrm{MeOH}-\mathrm{H}_{2} \mathrm{O}$ (2:8 to $\left.100: 0, \mathrm{v} / \mathrm{v}\right)$ to give 3 fractions (Fr.34.1-Fr.34.3). Fr.34.1 (420 $\mathrm{mg}$ ) was subjected to HPLC to give $35.6 \mathrm{mg}$ of compound 7 at RT $25 \mathrm{~min}$ and $10 \mathrm{mg}$ of compound $\mathbf{8}$ at RT $35 \mathrm{~min}$.

\subsection{Structure Determination and Characterization of Isolated Compounds}

The chemical structures of the isolated compounds were determined by spectroscopic methods, including mass spectroscopy (MS) and nuclear magnetic resonance (NMR) spectroscopy, and by comparison of their spectral data with values previously reported. High-resolution MS (HRMS) spectra were recorded using a Shimadzu LCMS-IT-TOF instrument (Kyoto, Japan) at atmospheric pressure chemical ionization (APCI) conditions. Ion source temperature was $300{ }^{\circ} \mathrm{C}$, the range of detection was $m / z 100-1200$, the potential in the ion source was $4.5 \mathrm{kV}$. The drying gas $\left(\mathrm{N}_{2}\right)$ pressure was $25 \mathrm{kPa}$. The nebulizer gas $\left(\mathrm{N}_{2}\right)$ flow was $2 \mathrm{~L} / \mathrm{min}$. The ${ }^{1} \mathrm{H}$ and ${ }^{13} \mathrm{C}-\mathrm{NMR}$, COSY, HMQC and HMBC spectra were recorded in deuterated NMR solvents using a Bruker AMX-500 FT-NMR spectrometer (Bruker Analytische Messtechnik Gmbh, Rheinstetten, Germany).

Trolliamide (1): White powder, negative HRESIMS m/z 680.6267 [M-H] $]^{-}\left(\mathrm{C}_{42} \mathrm{H}_{82} \mathrm{NO}_{5}\right)$; MS-MS m/z: 438.3970, 426.3982, 408.3839, 383.3558, 378.3768, 365.3436, 337.3475, 333.3180, 306.2467, 265.2134, 253.2201; ${ }^{1} \mathrm{H}-\mathrm{NMR}\left(\mathrm{C}_{5} \mathrm{D}_{5} \mathrm{~N}, 500 \mathrm{MHz}\right), \delta(\mathrm{ppm}): 4.51$ and $4.43(\mathrm{~m}, \mathrm{H}-1), 5.12(\mathrm{~m}, \mathrm{H}-2)$, 4.37 (m, H-3), 4.62 (m, H-4), 2.28 (m, H-5), 1.92 (m, H-6), 2.17 (m, H-7), 5.53 (m, H-8), 5.53 (m, H9), 1.99 (m, H-10), 1.30-1.20 (H-11 - H-17), 0.87 (m, H-18), 4.29 (m, H-2'), 2.03 (m, H-3'), 1.75 (m, H-4'), 1.30-1.20 (H-5' - H-23'), 0.87 (m, H-24'), 8.59 (d, $J=9.0, \mathrm{NH}) ;{ }^{13} \mathrm{C}-\mathrm{NMR}\left(\mathrm{C}_{5} \mathrm{D}_{5} \mathrm{~N}, 125 \mathrm{MHz}\right)$, $\delta$ (ppm): 61.79 (C-1), 52.57 (C-2), 76.63 (C-3), 72.80 (C-4), 33.93 (C-5), 26.29 (C-6), 33.61 (C-7), 130.59 (C-8), 130.47 (C-9), 33.08 (C-10), 30.11-29.28 (C-11 - C-15), 32.76 (C-16), 22.71 (C-17), 14.05 (C-18), 174.99 (C-1'), 72.24 (C-2'), 35.49 (C-3'), 25.59 (C4'), 30.11-29.28 (C-5' - C-21'), 31.89 (C22'), $22.71\left(\mathrm{C}-23^{\prime}\right), 14.05\left(\mathrm{C}-24^{\prime}\right)$.

Gallic acid (2): ${ }^{1} \mathrm{H}-\mathrm{NMR}\left(\mathrm{CD}_{3} \mathrm{OD}, 500 \mathrm{MHz}\right), \delta$ (ppm): $7.06(1 \mathrm{H}, \mathrm{s}, \mathrm{H}-2, \mathrm{H}-6) ;{ }^{13} \mathrm{C}-\mathrm{NMR}\left(\mathrm{CD}_{3} \mathrm{OD}\right.$, $125 \mathrm{MHz}), \delta$ (ppm): 122.1 (C-1), 110.4 (C-2, C-6), 146.30 (C-3, C-5), 139.5 (C-4), 170.6 (C-7).

Urolithin M-5 (3): ${ }^{1} \mathrm{H}-\mathrm{NMR}\left(\mathrm{CD}_{3} \mathrm{OD}, 500 \mathrm{MHz}\right), \delta(\mathrm{ppm}): 8.44(1 \mathrm{H}, \mathrm{d}, J=9.0 \mathrm{~Hz}, \mathrm{H}-1), 6.77(1 \mathrm{H}, \mathrm{d}$, $J=9.0 \mathrm{~Hz}, \mathrm{H}-2), 7.37$ (1H, s, H-7); ${ }^{13} \mathrm{C}-\mathrm{NMR}\left(\mathrm{CD}_{3} \mathrm{OD}, 125 \mathrm{MHz}\right), \delta(\mathrm{ppm}): 119.2(\mathrm{C}-1), 112.5(\mathrm{C}-2)$, 144.0 (C-3), 133.3 (C-4), 140.9 (C-4a), 163.9 (C-6), 112.0 (C-6a), 108.2 (C-7), 146.4 (C-8), 146.7 (C9), 141.9 (C-10), 118.5 (C-10a), 112.8 (C-10b).

Hydroquinone (4): ${ }^{1} \mathrm{H}-\mathrm{NMR}\left(\mathrm{CD}_{3} \mathrm{OD}, 500 \mathrm{MHz}\right), \delta$ (ppm): 7.08 (1H, s, H-2, H-3, H-5, H-6); ${ }^{13} \mathrm{C}-$ NMR (CD $\left.{ }_{3} \mathrm{OD}, 125 \mathrm{MHz}\right) ; \delta$ (ppm): 146.4 (C-1, C-4); 110.3 (C-2, C-3, C-5, C-6).

2,4-Dihydroxybenzoic acid (5): ${ }^{1} \mathrm{H}-\mathrm{NMR}\left(\mathrm{CD}_{3} \mathrm{OD}, 500 \mathrm{MHz}\right), \delta(\mathrm{ppm}): 7.42(1 \mathrm{H}, \mathrm{d}, J=2.0 \mathrm{~Hz}, \mathrm{H}-3)$, $7.44(1 \mathrm{H}, \mathrm{dd}, J=8.5 ; 2.0 \mathrm{~Hz}, \mathrm{H}-5), 6.80(1 \mathrm{H}, \mathrm{d}, J=8.5, \mathrm{H}-6) ;{ }^{13} \mathrm{C}-\mathrm{NMR}\left(\mathrm{CD}_{3} \mathrm{OD}, 125 \mathrm{MHz}\right) ; \delta$ (ppm): 123.2 (C-1), 151.5 (C-2), 123.9 (C-3), 146.0 (C-4), 117.7 (C-5), 115.7 (C-6), 170.3 (C-7). 
3,5-Dihydroxy-4-methoxybenzoic acid (6): ${ }^{1} \mathrm{H}-\mathrm{NMR}\left(\mathrm{CD}_{3} \mathrm{OD}, 500 \mathrm{MHz}\right), \delta(\mathrm{ppm}): 7.04(2 \mathrm{H}, \mathrm{s}, \mathrm{H}-2$, $\mathrm{H}-6), 3.82\left(3 \mathrm{H}, \mathrm{s}, 8-\mathrm{CH}_{3}\right) ;{ }^{13} \mathrm{C}-\mathrm{NMR}\left(\mathrm{CD}_{3} \mathrm{OD}, 125 \mathrm{MHz}\right) ; \delta(\mathrm{ppm}): 121.5$ (C-1), 110.0 (C-2, C-6), 146.5 (C-3, C-5), 169.0 (C-7), 52.2 (C-8).

Corilagin (7): ${ }^{1} \mathrm{H}-\mathrm{NMR}\left(500 \mathrm{MHz}, \mathrm{CD}_{3} \mathrm{OD}\right), \delta$ (ppm): 3,6- hexahydroxydiphenoyl (3,6-HHDP): 6.72 (H-5), 6.69 (H-5'); glucose: $6.41(\mathrm{H}-1), 4.00$ (H-2), 4.88 (H-3), 4.50 (H-4), 4.58 (H-5), 4.21 (H-6a), 5.00 (H-6b); 1-O-galloyl: 7.09 (H-2"' and H-6 $\left.6^{\prime \prime \prime}\right) .{ }^{13} \mathrm{C}-\mathrm{NMR}$ (125 MHz, CD $\mathrm{CDD}_{3}$ ), $\delta$ (ppm): 3,6-HHDP: 115.8 (C-1), 143.9 (C-2), 136.8 (C-3), 144.2 (C-4); 108.8 (C-5), 124.1 (C-6), 167.1 (C-7), 115.3 (C1'), 143.8 (C-2'), $136.3\left(\mathrm{C}-3^{\prime}\right), 144.7\left(\mathrm{C}-4^{\prime}\right), 107.0\left(\mathrm{C}-5^{\prime}\right), 124.1$ (C-6'), 168.7 (C-7'); glucose: 93.7 (C1), 68.1 (C-2), 70.2 (C-3), 61.1 (C-4), 74.8 (C-5), 63.6 (C-6); 1-O-galloyl: 119.3 (C-1"'), 109.6 (C-2"' and C-6"'), $145.0\left(\mathrm{C}-3^{\prime \prime \prime}\right.$ and $\left.\mathrm{C}-5^{\prime \prime \prime}\right), 139.0\left(\mathrm{C}-4^{\prime \prime \prime}\right), 165.4\left(\mathrm{C}-7^{\prime \prime \prime}\right)$.

Chebulagic acid (8): ${ }^{1} \mathrm{H}-\mathrm{NMR}\left(500 \mathrm{MHz}, \mathrm{CD}_{3} \mathrm{OD}\right), \delta$ (ppm): 3,6-HHDP: 6.84 (H-5), 6.64 (H-5'); glucose: $6.51(\mathrm{H}-1), 5.39$ (H-2), $5.83(\mathrm{H}-3), 5.23(\mathrm{H}-4), 4.90$ (H-6a), 4.39 (H-6b); 1-O-galloyl: 7.08 (H-2"' and H-6"'), 2-O-4-O-chebuloyl: $5.06\left(\mathrm{H}-3^{\prime}\right), 3.81\left(\mathrm{H}-4^{\prime}\right), 2.00\left(\mathrm{H}-5 \mathrm{a}^{\prime}\right), 1.20\left(\mathrm{H}-5 \mathrm{~b}^{\prime}\right), 7.48(\mathrm{H}-$ $\left.2^{\prime \prime}\right) .{ }^{13} \mathrm{C}-\mathrm{NMR}\left(125 \mathrm{MHz}, \mathrm{CD}_{3} \mathrm{OD}\right), \delta$ (ppm): 3,6-HHDP: 117.6 (C-1), 145.5 (C-2), 138.6 (C-3), 145.6 (C-4), 110.4 (C-5), 124.5 (C-6), 167.5 (C-7), 116.2 (C-1'), 145.3 (C-2'), 137.5 (C-3'), 146.1 (C-4'), $108.2\left(\mathrm{C}-5^{\prime}\right), 125.6$ (C-6'), 170.1 (C7'); glucose: 92.5 (C-1), 71.1 (C-2), 62.4 (C-3), 66.8 (C-4), 74.5 (C-5), 64.7 (C-6); 1-O-galloyl: 120.1 (C-1"'), 110.9 (C-2'"'and C-6"'), 146.5 (C-3"' and C-5"'), 140.8 (C-4"'), 166.2 (C-7'"'), 2-O-4-O-chebuloyl: 170.7 (C-1'), 67.0 (C-2'), 41.7 (C-3'), 40.0 (C-4'), 30.7 (C5'), 174.9 (C-6'), $174.4\left(\mathrm{C}-7^{\prime}\right), 119.0\left(\mathrm{C}-1^{\prime \prime}\right), 117.6$ (C-2"), 147.4 (C-3"), 140.4 (C-4"), 141.4 (C-5"), 115.9 (C-6"), 166.4 (C-7").

Shikimic acid (9): ${ }^{1} \mathrm{H}-\mathrm{NMR}\left(500 \mathrm{MHz}, \mathrm{CD}_{3} \mathrm{OD}\right), \delta(\mathrm{ppm}): 6.67(1 \mathrm{H}, \mathrm{m}, \mathrm{H}-2), 4.36(1 \mathrm{H}$, brt, $J=4.5 \mathrm{~Hz}$, H-3), 3.98 (m, H-5), 3.64 (1H, dd, $J=8.5,4.5 \mathrm{~Hz}, \mathrm{H}-4), 2.80$ (1H, dd, $J=18.0,5.0 \mathrm{~Hz}, \mathrm{H}-6 \alpha), 2.23$ $(1 \mathrm{H}, \mathrm{dd} J=18.0,7.0 \mathrm{~Hz}, \mathrm{H}-6 \beta) ;{ }^{13} \mathrm{C}-\mathrm{NMR}\left(500 \mathrm{MHz}, \mathrm{CD}_{3} \mathrm{OD}\right) \delta(\mathrm{ppm}): 134.26$ (C-1), 135.22 (C-2), 67.57 (C-3), 73.54 (C-4), 68.37 (C-5), 33.12 (C-6), 172.79 (C-7).

\subsection{Cells, Viruses and Antiviral Agents}

Influenza viruses PR8, HK and Lee were purchased from the American Type Culture Collection (ATCC). Influenza A viral strains (PR8 and HK) were amplified by infection of 10-day-old chicken eggs at $37^{\circ} \mathrm{C}$ for 3 days and influenza B virus (Lee) by infection of Madin-Darby canine kidney (MDCK) cells under serum-free conditions. MDCK cells were purchased from ATCC and maintained in minimum essential medium (MEM; Invitrogen) supplemented with $10 \%$ fetal bovine serum (FBS; Invitrogen) at $37^{\circ} \mathrm{C}$ in $5 \% \mathrm{CO}_{2}$. Antiviral agents, amantadine hydrochloride (AMT), ribavirin (RBV) (Sigma-Aldrich) and oseltamivir carboxylate (OSV-C; US Biological) were applied as positive control compounds.

\subsection{Cytopathic Effect (CPE) Inhibition Assay}

CPE was performed according to our previous report [26]. MDCK cells were seeded in 96-well plates and were mock-infected or infected with influenza virus at a multiplicity of infection (MOI) of 0.001 for $1 \mathrm{~h}$ at $35^{\circ} \mathrm{C}$ under serum-free conditions. Test materials dissolved in MEM with $2 \mu \mathrm{g} / \mathrm{mL}$ TPCK-trypsin were added to each well. Fluorescence intensity reflecting cell viability was measured using fluorescein diacetate (FDA; Sigma) at $485 / 538 \mathrm{~nm}$. The half maximal cytotoxic concentration $\left(\mathrm{CC}_{50}\right)$ and the half maximal effective concentration $\left(\mathrm{EC}_{50}\right)$ were calculated using GraphPad Prism 6 (GraphPad Software). The selectivity index (S.I.) is expressed as the ratio of $\mathrm{CC}_{50}$ to $\mathrm{EC}_{50}$.

\subsection{Statistical Analysis}

Statistically significant differences were determined using two tailed Student's t-test. $\mathrm{P}<0.05$ was considered significant. 


\section{Results and Discussion}

\subsection{Isolation and Identification of Metabolites from E. tonkinensis}

Nine pure metabolites were isolated and identified from the n-hexane and EtOAc residues of $E$. tonkinensis (Figure 1). Compound $\mathbf{1}$ was obtained as a white powder. The structure of this compound (Figure 1) can be established by 1D and 2D NMR spectra in combination with the MS data. Its molecular formula was determined as $\mathrm{C}_{42} \mathrm{H}_{83} \mathrm{NO}_{5}$ by negative HRESIMS at $\left.m / z 680.6279[\mathrm{M}-\mathrm{H}]\right]^{-}$. The NMR spectra suggested a ceramide structure. Thus, in the ${ }^{1} \mathrm{H}-\mathrm{NMR}$ spectrum, the strong $\left(\mathrm{CH}_{2}\right)_{\mathrm{n}}$ signals at $\delta 1.30$ and two terminal methyl signals at $\delta 0.87$ also confirmed the ceramidic nature of this compound. The ${ }^{1} \mathrm{H}-\mathrm{NMR}$ signal at $\delta 5.12(1 \mathrm{H}, m)$ was assignable to $\mathrm{H}(2)$, which coupled with signals at $\delta 4.51(1 \mathrm{H}, m, \mathrm{H}(1)), 4.43(1 \mathrm{H}, m, \mathrm{H}(1))$ and $4.37(1 \mathrm{H}, m, \mathrm{H}(3))$. In the ${ }^{13} \mathrm{C}$ NMR spectrum, the signals of three characteristic ceramide groups appeared at $\delta 175.0$ (amide carbon), 52.6 (nitrogenated carbon), and 29.9 (the $\left(\mathrm{CH}_{2}\right)_{\mathrm{n}}$ signals). $\mathrm{C}(1)$ and $\mathrm{C}(3)$ were assigned to the signals at $\delta 61.8$ and 76.6, indicating $\mathrm{C}(3)$ of chain A was hydroxylated. The coupling of $\mathrm{H}(3)$ and $\mathrm{H}(4)$ in COSY spectrum indicated the presence of hydroxyl group at $\mathrm{C}(4)$. The $\mathrm{C}\left(2^{\prime}\right)(\delta$ 72.24) of chain B was also demonstrated to be hydroxylated from the correlation between the carbonyl signal at $\delta 175.0(\mathrm{C}(1))$ and $4.29\left(1 \mathrm{H}, m, \mathrm{H}\left(2^{\prime}\right)\right)$. The geometry of double bond at $\Delta^{8}$ was determined to be trans as evidenced by allylic methylenes at $\delta 33.6(\mathrm{C}(7))$ and $33.1(\mathrm{C}(10))$ [11]. The structures of chain A and B were determined by the analysis of fragmentation patterns in the HRESI MS/MS spectrum (Figure 2). In this spectrum, the chain A can be seen through fragments with $m / z 223.2080\left(\mathrm{C}_{15} \mathrm{H}_{17} \mathrm{O}^{-}\right), 253.2140$ $\left(\mathrm{C}_{16} \mathrm{H}_{18} \mathrm{O}_{2}{ }^{-}\right)$and $426.3968\left(\mathrm{C}_{26} \mathrm{H}_{52} \mathrm{NO}_{3}{ }^{-}\right)$. The chain $\mathrm{B}$ can be proved on the basis of fragments with $\mathrm{m} / \mathrm{z}$ $337.350\left(\mathrm{C}_{23} \mathrm{H}_{45} \mathrm{O}^{-}\right), 365.346\left(\mathrm{C}_{24} \mathrm{H}_{45} \mathrm{O}_{2}{ }^{-}\right)$, and $383.3578\left(\mathrm{C}_{24} \mathrm{H}_{47} \mathrm{O}_{3}{ }^{-}\right)$. Based on the analysis of spectral data combined with literature data [12], the compound 1 was confirmed to be trolliamide.

Compounds 2, 3, and $\mathbf{6}$ were determined from their 1D-NMR spectra as gallic acid and its derivatives with six aromatic carbon signals and a carbonyl group. Compound $\mathbf{2}$ was identical to gallic acid on the basis of 1D-NMR data analysis and comparison with those in the literature [13].

Compound 6 was identified as methoxy derivative of compound 2 . The ${ }^{13} \mathrm{C}-\mathrm{NMR}$ spectra of compound 3 presented of 13 carbon signals in the range $\delta$ 108.2-163.9 suggested the presence of two aromatic rings and one lactone ring. One of the aromatic rings had characteristic carbon signals of gallic acid, comprising a carbonyl group at $\delta 163.9$ and six aromatic carbons from $\delta 112.0$ to 146.7. The chemical structure of compound $\mathbf{3}$ was determined by comparison with literature NMR data $[14,15]$. Compound 3 was identical to urolithin M-5, and was obtained as light brown crystals. Compounds $\mathbf{4}$ and $\mathbf{5}$ were determined by the analysis of spectra data combined with literature data $[16,17]$. Compounds 4 and $\mathbf{5}$ were determined to be hydroquinone $\left(\mathrm{C}_{6} \mathrm{H}_{6} \mathrm{O}_{2}\right)$ and 2,4-dihydroxybenzoic acid $\left(\mathrm{C}_{7} \mathrm{H}_{6} \mathrm{O}_{4}\right)$, respectively.

Compounds $\mathbf{7}$ and $\mathbf{8}$ were the first time isolated from this species. Their chemical structures were described as shown in Figure 1. The NMR spectra of compound 7 showed a hexahydroxydiphenoylD-glucose (HHDP-D-glucose) group and a galloyl group. The ${ }^{1} \mathrm{H}-\mathrm{NMR}$ spectra showed three singlet peaks, including two proton signals of the HHDP group at $\delta 6.69$ and 6.72 and one proton signal of the galloyl group at $\delta 7.09$. In addition, six signals appeared in the range of $\delta 4.00-6.41$ belong to a glucose ring. The ${ }^{13} \mathrm{C}$-NMR spectra also showed six carbon signals of the glucose ring at $\delta 61.1-93.7$. Moreover, the carbon signals of the galloyl group appeared at $\delta$ 109.6-165.4. The fourteen remaining carbon signals were assigned to the HHDP group. The proton-bearing carbons assigned by the HMQC spectra showed the linking position of the galloyl and HHDP groups with glucose ring. A methine proton of glucose ring at $\delta 4.88(\mathrm{H}(3))$ indicated $\mathrm{HMBC}$ correlations with carbon signal of the carbonyl group at $\delta 167.2(\mathrm{C}(\mathrm{A}-7))$ and methylene protons of glucose ring at $\delta 4.21$ and $5.00(\mathrm{H}(6))$ indicated correlations with ${ }^{13} \mathrm{C}-\mathrm{NMR}$ signal at $\delta 168.7(\mathrm{C}(\mathrm{B}-7))$ led to linking position of the HHDP group with $\mathrm{H}(3)$ and $\mathrm{H}(6)$ of the glucose ring. Similarly, the galloyl group ( $\delta$ 165.4) linked with $\mathrm{H}(1)$ $(\delta 6.41)$ of the glucose ring. From these data and the comparison of spectral data of compound 7 with literature data [18], compound 7 was determined to be corilagin. The NMR spectra of compound $\mathbf{8}$ were similar to those of compound 7 with some differences with the presence of 2-O-4-O-chebuloyl group. This analysis and comparison with literature [19] suggested compound $\mathbf{8}$ to have the same rearranged tannin structure, and compound $\mathbf{8}$ was identified as chebulagic acid. 
Compound 9 was demonstrated as shikimic acid by the analysis of spectral data and comparison with literature data [20]. Its ${ }^{1} \mathrm{H}-\mathrm{NMR}$ spectra showed a methine proton at $\delta 6.67$, three oxygenated methin protons at $\delta 4.36(b r t, J=4.5 \mathrm{~Hz}, \mathrm{H}(3)), 3.98(m, \mathrm{H}(5)), 3.64(d d, J=8.5,4.5 \mathrm{~Hz}, \mathrm{H}(4))$ and two methylene protons at $\delta 2.80(d d, J=18.0,5.0, \mathrm{~Hz}, \mathrm{H}(6 \alpha)), 2.23(d d, J=18.0,7.0 \mathrm{~Hz}, \mathrm{H}(6 \beta))$. The ${ }^{13} \mathrm{C}-\mathrm{NMR}$ spectrum of 9 had seven carbon signals. At low field, a carbon signal shown at $\delta 172.8$ belongs to carbonyl carbon. In addition, two olefin carbons also appeared at $\delta 134.3$ and 135.2 and one methylene carbon shown at $\delta 33.1$. The remaining carbon signals appeared at 67.6-73.5 assigned to three oxygenated carbons.

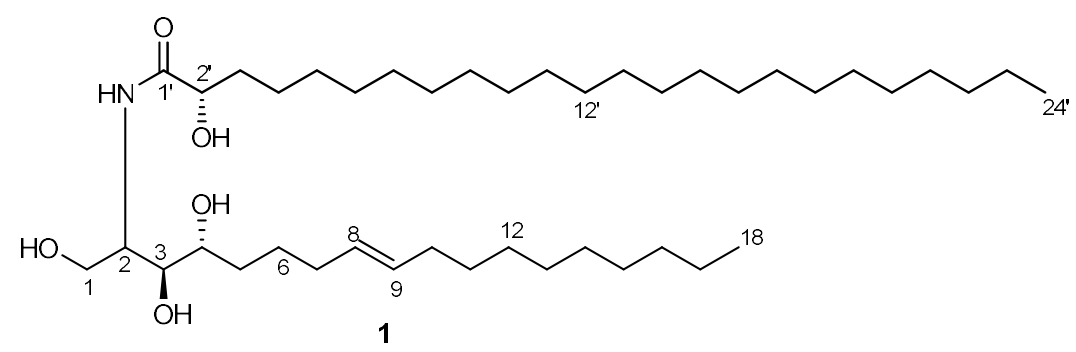<smiles>O=C(O)c1cc(O)c(O)c(O)c1</smiles>

2<smiles>O=c1oc2c(O)c(O)ccc2[o+]c1O</smiles><smiles>Oc1ccc(O)cc1</smiles><smiles>O=C(O)c1ccc(O)cc1O</smiles>

5<smiles>COc1c(O)cc(C(=O)O)cc1O</smiles>

6

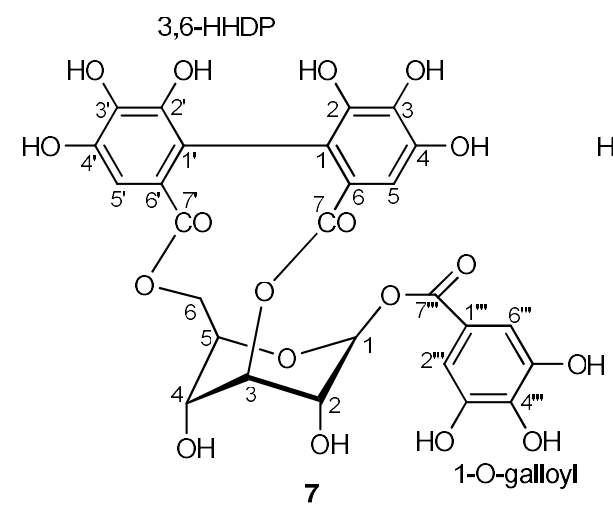<smiles>O=C(O)C1=C[C@@H](O)[C@H](O)[C@H](O)C1</smiles>

9

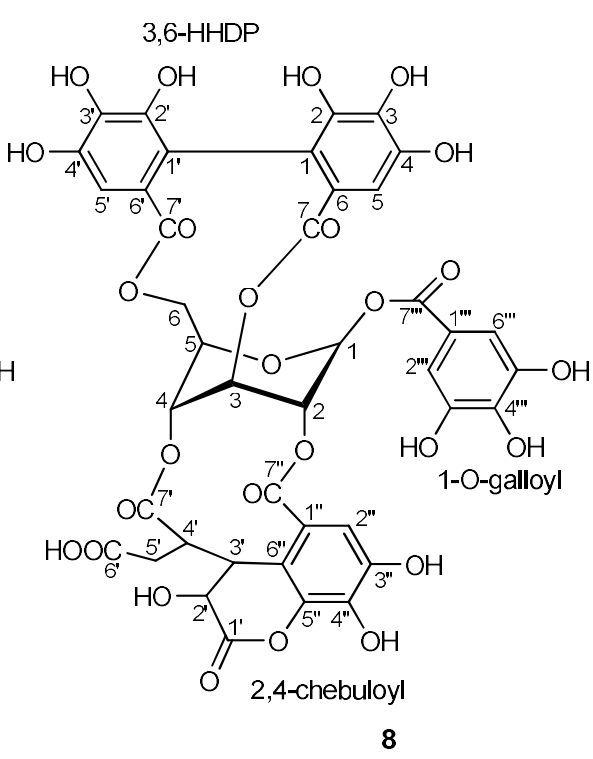

Figure 1. Chemical structures of the compounds isolated from E. tonkinensis. 


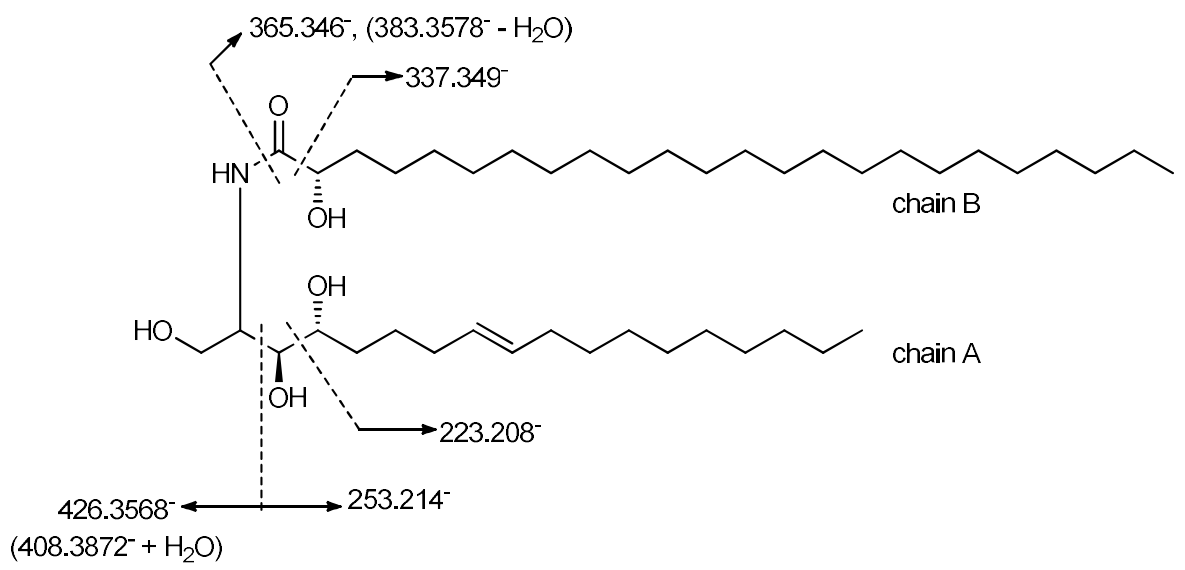

Figure 2. Selective fragmentation patterns in the mass spectra of compound 1 (trolliamide) isolated from E. tonkinensis. MS spectra were recorded using a Shimadzu LCMS-IT-TOF instrument at atmospheric pressure chemical ionization (APCI) conditions.

\subsection{Anti-influenza Activity of Crude Extract and Residues of E. tonkinensis}

Anti-influenza viral activity of E. tonkinensis $n$-hexane, DCM and EtOAc residues and $\mathrm{MeOH}$ extract was presented in Table 1. $n$-Hexane and DCM residues did not show any antiviral activity under the subtoxic concentrations lower than $280.0 \mu \mathrm{g} / \mathrm{mL}$ and $111.2 \mu \mathrm{g} / \mathrm{mL}$, respectively. Among them, $\mathrm{MeOH}$ extract showed the most potent inhibitory effects with $\mathrm{EC}_{50}$ values $19.8 \mu \mathrm{g} / \mathrm{mL}$ for PR8, $5.1 \mu \mathrm{g} / \mathrm{mL}$ for $\mathrm{HK}$, and $107.7 \mu \mathrm{g} / \mathrm{mL}$ for Lee strains. In contrast, the EtOAc residue exhibited marginal antiviral activity with $\mathrm{EC}_{50}$ values ranging between $52.7 \mu \mathrm{g} / \mathrm{mL}$ and $205.0 \mu \mathrm{g} / \mathrm{mL}$ for all strains. Moreover, it is noteworthy that the $\mathrm{MeOH}$ extract and EtOAc residue were not cytotoxic to MDCK cells at the highest concentration used $(300.0 \mu \mathrm{g} / \mathrm{mL})$.

Table 1. Antiviral activity of the crude extracts from E. tonkinensis against influenza viruses in the cytopathic effect (CPE) reduction assay.

\begin{tabular}{|c|c|c|c|c|c|}
\hline \multirow[b]{2}{*}{ Sample } & \multirow{2}{*}{$\mathrm{CC}_{50}{ }^{\mathrm{a}}$} & \multicolumn{3}{|l|}{$\mathrm{EC}_{50}{ }^{\mathrm{b}}\left(\right.$ S.I. $\left.^{\mathrm{c}}\right)$} & \multirow[b]{2}{*}{ - Unit } \\
\hline & & $\mathrm{PR}^{\mathrm{d}}$ & $\mathrm{HK}^{\mathrm{e}}$ & $\operatorname{Lee}^{f}$ & \\
\hline $\mathrm{Hex}^{\mathrm{g}}$ & $280.0 \pm 19.3$ & $>280.0$ (N.A. $\left.{ }^{\mathrm{n}}\right)$ & $>280.0\left(\right.$ N.A. $\left.{ }^{\mathrm{n}}\right)$ & $>280.0$ (N.A. $\left.{ }^{\mathrm{n}}\right)$ & $\mu \mathrm{g} / \mathrm{mL}$ \\
\hline $\mathrm{DCM}^{\mathrm{h}}$ & $111.2 \pm 6.6$ & $>111.2$ (N.A." ) & $>111.2$ (N.A." $)$ & $>111.2$ (N.A." $)$ & $\mu \mathrm{g} / \mathrm{mL}$ \\
\hline $\mathrm{MeOH}^{\mathrm{i}}$ & $>300.0$ & $19.8 \pm 1.9(>15.2)$ & $5.1 \pm 0.3(>59.4)$ & $107.7 \pm 40.6(>2.8)$ & $\mu \mathrm{g} / \mathrm{mL}$ \\
\hline $\mathrm{EtOAc}^{\mathrm{i}}$ & $>300.0$ & $79.6 \pm 18.3(>3.8)$ & $52.7 \pm 3.4(>5.7)$ & $205.0 \pm 24.1(>1.5)$ & $\mu \mathrm{g} / \mathrm{mL}$ \\
\hline $\mathrm{AMT}^{\mathrm{k}}$ & $>100.0$ & $>100.0$ (N.A." $)$ & $3.2 \pm 1.6(>31.3)$ & $>100.0$ (N.A. $\left.{ }^{n}\right)$ & $\mu \mathrm{M}$ \\
\hline $\mathrm{RBV}^{1}$ & $>100.0$ & $55.6 \pm 1.3(>1.8)$ & $56.9 \pm 0.8(>1.8)$ & $52.2 \pm 8.3(>1.9)$ & $\mu \mathrm{M}$ \\
\hline $\mathrm{OSV}-\mathrm{C}^{\mathrm{m}}$ & $>100.0$ & $0.29 \pm 0.05(>344.8)$ & $0.01 \pm 0.00(>11,764.7)$ & $2.36 \pm 1.35(>42.5)$ & $\mu \mathrm{M}$ \\
\hline
\end{tabular}

\subsection{Anti-influenza Viral Activity of Isolated Compounds}

CPE inhibition assay was further performed for evaluating anti-influenza viral activity of the 9 isolated compounds (Table 2 and Figure 3). Compounds $\mathbf{1}$ and $\mathbf{5}$ displayed marginal or no antiinfluenza activity and no cytotoxicity to MDCK cells at $300 \mu \mathrm{g} / \mathrm{mL}$.

Compounds 2, 3 and $\mathbf{6}$ are belonging to gallic acid and its derivatives (Figure 1). Out of those, compounds $\mathbf{2}$ and $\mathbf{3}$, but not $\mathbf{6}$ (displayed marginal), showed activity against influenza A and B strains with SI values above 5 against all viruses tested (Table 2). In terms of selectivity, compound 2 (gallic 
acid) exhibited effectively activity against influenza with $\mathrm{EC}_{50}$ values of $8.1,7.8$ and $19.4 \mu \mathrm{g} / \mathrm{mL}$ against PR8, HK and Lee, respectively, with a $\mathrm{CC}_{50}$ value of about $161.4 \mu \mathrm{g} / \mathrm{mL}$, that is consistent to previous reports [21,22]. Although compound 3 (urolithin M-5) showed weaker antiviral activity than compound 2, it was remarkably active against the influenza $\mathrm{A}$ and $\mathrm{B}$ viruses with $\mathrm{EC}_{50}$ values of 34.3 to $59.6 \mu \mathrm{g} / \mathrm{mL}$ comparably. Most of all, this is the first observation supporting that urolithin M-5 has anti-influenza viral function. The anti-influenza viral activity of gallic acid and its derivatives could be associated with their planar structure and cell membrane permeability, as described previously (Kaihatsu et al. 2014). When compared to compounds $\mathbf{2}$ and $\mathbf{3}$, another gallic acid derivative, compound 6 lost antiviral activity dramatically $\left(\mathrm{EC}_{50}\right.$ values between 127.9 to $206.1 \mu \mathrm{g} / \mathrm{mL}$ ), suggesting that hydroxyl group at $\mathrm{C} 4$ of gallic acid is essential for suppressing viral growth.

Compound 4 showed anti-influenza viral activity with an $\mathrm{EC}_{50}$ of $31.9,19.7$ and $54.3 \mu \mathrm{g} / \mathrm{mL}$ for PR8, HK and Lee, respectively. The tannin compounds, compounds 7 and 8 also showed desirable antiviral activity against PR8, HK and Lee without cytotoxicity or an abnormally increase in cell viability at the maximum concentration treated $(300.0 \mu \mathrm{g} / \mathrm{mL})$ (Table 2 and Figure 3). Compound 7 showed activity against influenza $\mathrm{A}$ virus with an $\mathrm{EC}_{50}$ of 31.2 and $36.8 \mu \mathrm{g} / \mathrm{mL}$ for PR8 and $\mathrm{HK}$, respectively. Particularly, compound $\mathbf{8}$ revealed anti-influenza viral activity with $\mathrm{EC}_{50}$ values of 21.0, 29.0 and $58.8 \mu \mathrm{g} / \mathrm{mL}$ for PR8, HK and Lee, respectively. Although compound 9 showed antiviral activity against three influenza virus strains with $\mathrm{EC}_{50}$ values between 26.3 and $71.4 \mu \mathrm{g} / \mathrm{mL}$, its cytotoxicity was severe with $\mathrm{CC}_{50}$ of $141.2 \mu \mathrm{g} / \mathrm{mL}$ as observed in compound 2 . In spite of its cytotoxicity, the anti-influenza viral activity of compound 9 was reported in previous studies [23,24]. It was also used as a primary structure to synthesize oseltamivir phosphate, an antiviral drugs with a brand name of Tamiflu [25] (Table 2 and Figure 3).

Table 2. Antiviral activity of the substances isolated from E. tonkinensis against influenza viruses in the cytopathic effect (CPE) reduction assay.

\begin{tabular}{|c|c|c|c|c|c|}
\hline \multirow{2}{*}{ Chemical } & \multirow{2}{*}{$\mathrm{CC}_{50}{ }^{\mathrm{a}}$} & \multicolumn{3}{|c|}{$\mathrm{EC}_{50}{ }^{\mathrm{b}}\left(\right.$ S.I. $\left.^{\mathrm{c}}\right)$} & \multirow{2}{*}{ Unit } \\
\hline & & $\mathrm{PR}^{\mathrm{d}}$ & $\mathrm{HK}^{\mathrm{e}}$ & $\mathrm{Lee}^{\mathrm{f}}$ & \\
\hline $\mathbf{1}^{\mathrm{g}}$ & $>300.0$ & $>300.0$ (N.A. $\left.{ }^{\mathrm{s}}\right)$ & $122.1 \pm 22.1(>2.5)$ & $>300.0$ (N.A. $\left.{ }^{\mathrm{s}}\right)$ & $\mu \mathrm{g} / \mathrm{mL}$ \\
\hline $2^{h}$ & $161.4 \pm 13.8$ & $8.1 \pm 0.0(20.0)$ & $7.8 \pm 0.3(20.8)$ & $19.4 \pm 2.2(8.3)$ & \\
\hline $3^{\mathbf{i}}$ & $>300.0$ & $58.9 \pm 0.3(>5.1)$ & $34.3 \pm 13.5(>8.8)$ & $59.6 \pm 0.8(>5.0)$ & $/ \mathrm{mL}$ \\
\hline $4^{\mathrm{j}}$ & $>300.0$ & $31.9 \pm 10.8(>9.4)$ & $19.7 \pm 3.4(>15.3)$ & $54.3 \pm 1.6(>5.5)$ & $\mathrm{nL}$ \\
\hline $5^{k}$ & $>300.0$ & $>300.0$ (N.A. $\left.{ }^{\mathrm{s}}\right)$ & $>300.0$ (N.A. ${ }^{\mathrm{s}}$ ) & $154.1 \pm 26.4(>1.9)$ & $\mu \mathrm{g} / \mathrm{mL}$ \\
\hline $6^{1}$ & $>300.0$ & $130.2 \pm 5.6(>2.3)$ & $127.9 \pm 4.5(>2.3)$ & $206.1 \pm 48.3(>1.5)$ & $\mu \mathrm{g} / \mathrm{mL}$ \\
\hline $7^{m}$ & $>300.0$ & $31.2 \pm 0.7(>9.6)$ & $36.8 \pm 8.1(>8.2)$ & $160.3 \pm 7.2(>1.9)$ & $\mu \mathrm{g} / \mathrm{mL}$ \\
\hline $8^{n}$ & $>300.0$ & $21.0 \pm 1.8(>14.3)$ & $29.0 \pm 13.6(>10.3)$ & $58.8 \pm 2.6(>5.1)$ & $\mu \mathrm{g} / \mathrm{mL}$ \\
\hline $9^{\circ}$ & $141.2 \pm 11.5$ & $61.4 \pm 15.8(>2.3)$ & $26.3 \pm 3.8(>5.4)$ & $71.4 \pm 9.0(>2.0)$ & $\mu \mathrm{g} / \mathrm{mL}$ \\
\hline $\mathrm{AMT}^{\mathrm{p}}$ & $>100.0$ & $>100.0$ (N.A. ${ }^{\mathrm{s}}$ ) & $2.0 \pm 0.2(>50.0)$ & $>100.0$ (N.A. ${ }^{\mathrm{s}}$ ) & $\mu \mathrm{M}$ \\
\hline $\mathrm{RBV}^{\mathrm{q}}$ & $>100.0$ & $35.2 \pm 7.9(>2.8)$ & $17.0 \pm 0.2(>5.9)$ & $19.4 \pm 0.5(>5.2)$ & $\mu \mathrm{M}$ \\
\hline $\mathrm{OSV}-\mathrm{C}^{\mathrm{r}}$ & $>100.0$ & $0.21 \pm 0.06(>476.2)$ & $<0.005(>20,000.0)$ & $1.08 \pm 0.22(>92.6)$ & $\mu \mathrm{M}$ \\
\hline \multicolumn{6}{|c|}{ 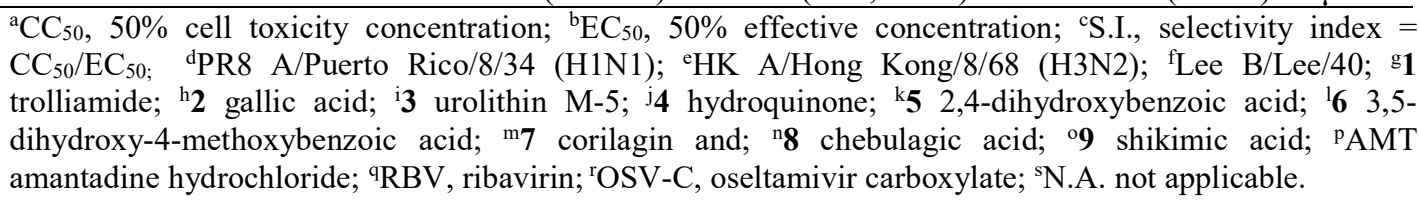 } \\
\hline
\end{tabular}

\section{Conclusions}

This is the first report on isolation, identification and anti-influenza virus activity of the compounds isolated from E. tonkinensis. The $\mathrm{MeOH}$ extract and EtOAc layer of E. tonkinensis exhibited antiviral activity against influenza viruses of $\mathrm{A} / \mathrm{H} 1 \mathrm{~N} 1, \mathrm{~A} / \mathrm{H} 3 \mathrm{~N} 2$ and $\mathrm{B}$. Out of constituents isolated from the EtOAc layer, gallic acid, urolithin M-5, hydroquinone, corilagin, chebulagic acid and shikimic acid showed significant anti-influenza viral activity. Our study suggests that the botanical materials of $E$. tonkinensis could be promising inhibitors of influenza A and B viruses and applied to the development of a novel herbal medicine. 


\section{Acknowledgments}

The work was completed with financial support from the project of National Foundation for Science and Technology Development (104.01-2014.34.) and also with a fund from KRICT (KK1803E00 for M. Kim).

\section{Supporting Information}

Supporting information accompanies this paper on http://www.acgpubs.org/RNP

\section{ORCID}

Nga Thu Dao: 0000-0001-6960-0360

Meehyein Kim: 0000-0002-2851-5298

Yejin Jang: 0000-0002-2440-7839

Hung Huy Nguyen: 0000-0002-5580-2487

Minh Van Nguyen: 0000-0001-5606-6197

Duong Quang Pham: 0000-0002-3036-8581

Bong-Sik Yun: 0000-0002-0594-8955

Quan Minh Pham: 0000-0001-6922-1627

Jin-Cheol Kim: 0000-0003-0753-1966

Quang Le Dang: 0000-0001-7203-8081

Vu Dinh Hoang: 0000-0002-2112-6732

\section{References}

[1] P. H. Ho (1999). Cay co Viet Nam, Tre Publishing House, Hanoi.

[2] A. Dadhich, A. Rishi, G. Sharma, and S. Chandra (2013). Phytochemicals of Elaeocarpus with their therapeutic value: a review, Int. J. Pharm. Bio. Sci. 4, 591-598.

[3] G. Shah, P. S. Singh, A. S. Mann, and R. Shri (2011). Scientific basis for the chemical constituents and therapeutic use of Elaeocarpus species: a review, Int. J. Inst. Pharm. Life. Sci. 1, 267-278.

[4] A. D. Kinghorn, N. R. Farnsworth, D. D. Soejarto, G. A. Cordell, S. M. Swanson, J. M. Pezzuto, M. C. Wani, M. E. Wall, N. H. Oberlies, D. J. Kroll, R. A. Kramer, W. C. Rose, G. D. Vite, C. R. Fairchild, R. W. Peterson, and R. Wild (1999). Novel strategies for the discovery of plant-derived anticancer agents, Pure Appl. Chem. 71, 1611-1618.

[5] S. Tripathy, A. Mida, and S. R. Swain (2016). Antimicrobial and hypoglycemic effects of Elaeocarpus ganitrus seed, Imperial. J. Interdisc. Res. 2, 1692-1696.

[6] T. Pullaiah (2006). Encyclopedia of world medicinal plants, $2^{\text {nd }}$ ed., Regency Publication, New Delhi.

[7] A. K. Hule, A. S. Shah, M. N. Gambhire, and A. R. Juvekar (2011). An evaluation of the antidiabetic effects of Elaeocarpus ganitrus in experimental animals, Indian J. Pharmacol. 43, 56-59.

[8] C. Bualee, A. Ounaroon, and R. Jeenapongsa (2007). Antidiabetic and long-term effects of Elaeocarpus grandiflorus, Naresuan Univ. J. 15, 17-28.

[9] A. R. Carroll, G. Arumugan, R. J. Quinn, J. Redburn, G. Guymer, and P. Grimshaw (2005). Grandisine A and $\mathrm{B}$, Novel indolizidine alkaloids with human $\delta$-opioid receptor binding affinity from the leaves of the Australian rainforest tree Elaeocarpus grandis, J. Org. Chem.70, 1889-1892.

[10] R. K. Singh, S. K. Bhattacharya, and S. B. Acharya (2000). Studies on extracts of Elaeocarpus sphaericus fruits on in vitro rat mast cells, Phytomedicine 7, 205-207.

[11] R. A. Barrow, and R. J. Capon (1991). Alkyl and alkenyl resorcinols from an Australian marine sponge, Haliclona sp (Haplosclerida, Haliclonidae). Aust. J. Chem. 44, 1393-1405.

[12] R.-F. Wang, R.-N. Liu, T. Zhang, and T. Wu (2010). A new natural ceramide from Trollius chinensis Bunge, Molecules 15, 7467-7471.

[13] S. Kamatham, N. Kumar, and P. Gudipalli (2015). Isolation and characterization of gallic acid and methyl gallate from the seed coats of Givotia rottleriformis Griff. and their anti-proliferative effect on human epidermoid carcinoma A431 cells, Toxicol. Rep. 2, 520-529.

[14] H. Ito, A. Iguchi, and T. Hatano (2008). Identification of urinary and intestinal bacterial metabolites of ellagitannin geraniin in rats. J Agric Food Chem. 56, 393-400.

[15] Z. Zhang, L. Liao, J. Moore, T. Wu, and Z. Wang (2009). Antioxidant phenolic compounds from walnut kernels (Juglans regia L.), Food Chem. 113, 160-165. 
[16] V. Jeyanthi, P. Anbu, M. Vairamani, and P. Velusamy (2015). Isolation of hydroquinone (benzene-1,4diol) metabolite from halotolerant Bacillus methylotrophicus MHC10 and its inhibitory activity towards bacterial pathogens, Bioprocess Biosyst. Eng. 39, 429-439.

[17] M. Jadrijević-Mladar, M. Takac, D. V. Topić, and T. Govorcinović (2004). FT-IR and NMR spectroscopic studies of salicylic acid derivatives. II. Comparison of 2-hydroxy-and 2,4- and 2,5dihydroxy derivatives, Acta. Pharm. 54, 177-191.

[18] Y. Sudjaroen, W. E. Hull, G. Erben, G. Würtele, S. Changbumrung, C. M. Ulrich, and R. W. Owen (2012). Isolation and characterization of ellagitannins as the major polyphenolic components of Longan (Dimocarpus longan Lour) seeds, Phytochemistry 77, 226-237.

[19] B. Pfundstein, S. K. El-Desouky, W. E. Hull, R. Haubner, G. Erben, and R. W. Owen (2010). Polyphenolic compounds in the fruits of Egyptian medicinal plants (Terminalia bellerica, Terminalia chebula and Terminalia horrida): characterization, quantitation and determination of antioxidant capacities, Phytochemistry 71, 1132-1148.

[20] M. Liu, S. Yang, L. Jin, D. Hu, Z. Wu, and S. Yang (2012). Chemical constituents of the ethyl acetate extract of Belamcanda chinensis (L.) DC roots and their antitumor activities, Molecules 17, 6156-6169.

[21] G. H. Chen, Y. L. Lin, W. L. Hsu, S. K. Hsieh, and J. T. C. Tzen (2015). Significant elevation of antiviral activity of strictinin from Pu'er tea after thermal degradation to ellagic acid and gallic acid, $J$. Food Drug Anal. 23, 116-123.

[22] K. Kaihatsu, C. Kawakami, and N. Kato (2014). Potential anti-influenza virus agents based on coffee ingredients and natural flavonols, Nat. Prod. Chem. Res. 2, 129.

[23] A. A. Bertelli, C. Mannari, S. Santi, C. Filippi, M. Migliori, and L. Giovannini (2008). Immunomodulatory activity of shikimic acid and quercitrin in comparison with oseltamivir (Tamiflu) in an "in vitro" model, J. Med. Virol. 80, 741-745.

[24] T. Kuang, C. Lu, and L. Zhang (2013). Photosynthesis research for food, fuel and future: 15th International conference on photosynthesis, Springer-Verlag Berlin Heidelberg, Berlin.

[25] L.-D. Nie, X.-X. Shi, K. H. Ko, and W.-D. Lu (2009). A short and practical synthesis of Oseltamivir phosphate (Tamiflu) from (-)-shikimic acid, J. Org. Chem. 74, 3970-3973.

[26] M. Kim, S. Y. Kim, H. W. Lee, J. S. Shin, P. Kim, Y. S. Jung, H. S. Jeong, J. K. Hyun, and C. K. Lee (2013). Inhibition of influenza virus internalization by (-)-epigallocatechin-3-gallate, Antiviral Res. 100, 460-472.

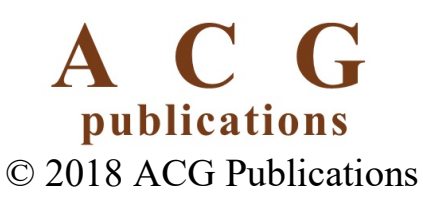

